\title{
Analisis Keragaman Hasil Kegiatan \\ Mahasiswa Peserta Kuliah Kerja Nyata \\ Institut Seni Indonesia Denpasar \\ Pada Masa Pandemic Covid-19 Tahun 2020
}

\section{Gede Yudarta, Ni Putu Leslyani, Ni Putu Ayu Putri Artini, Agus Eka Wahyu- wiarsana, I Gede Nanda Krisdiawan, I Komang Arsana, I Gede Ngurah Bayu Pratama, I Wayan Gede Prianta, I Wayan Edi Apriawan}

\author{
Program Studi Seni Karawitan \\ Fakultas Seni Pertunjukan \\ Institut Seni Indonesia Denpasar \\ gedeyudarta@isi-dps.ac.id
}

Penyusunan artikel ini betujuan untuk mendeskripsikan hasil kegiatan Kuliah Kerja Nyata (KKN) yang dilakukan oleh mahasiswa Institut Seni Indonesia (ISI) Denpasar pada pelaksanaan KKN periode tahun 2020. Sebagai salah satu kegiatan Tri Dharma Perguruan Tinggi, pelaksanaan KKN ISI Denpasar merupakan implementasi penerapan hasil pembelajaran yang diperoleh mahasiswa di bangku kuliah. Berbeda dengan pelaksanaan KKN pada tahun-tahun sebelumnya, berkenaan dengan pandemic Corona Virus Disease (Covid-19) kegiatan KKN diarahkan untuk meningkatkan kapasitas mahasiswa dengan cara terlibat langsung berpartisipasi aktif melakukan upaya membantu masyarakat di daerah asalnya masing-masing untuk pencegahan, pemutusan mata rantai penyebaran Covid-19. Pada pelaksanaan KKN 2020, mahasiswa dibagi dalam beberapa kelompok dimana pada setiap kelompok terdapat mahasiswa dari berbagai program studi. Pada Kelompok 16 terdapat 8 orang mahasiswa dari Prodi Desain Mode, Prodi Tari, Prodi Produksi Film dan Televisi, Prodi Pendidikan Seni Pertunjukan, Prodi Pedalangan, Prodi Karawitan, dan Prodi Seni Murni. Adapun program kerja yang dilaksanakan oleh mahasiswa adalah sesuai dengan bidang yang dipelajari pada masing-masing prodi. Berkenaan dengan hal tersebut, di dalam artikel ini terdapat beberapa pokok bahasan diantaranya berkaitan dengan program kerja yang dilakukan, realisasi program kerja dan faktor penghambat dan pendukung di dalam pelaksanaan program kerja. Metode yang digunakan di dalam penulisan artikel ini adalah metode kualitatif dimana data diperoleh dari hasil laporan kegiatan mahasiswa selanjutnya data tersebut dianalisis dan dideskripsikan sesuai dengan kaidah penulisan ilmiah. Kesimpulan tulisan ini berupa analisis hasil program kerja mahasiswa, realisasi program kerja serta faktor-faktor yang menjadi penghambat dan pendukung pelaksanaan KKN dimasa pandemic Covid-19.

\section{Kata Kunci: KKN, ISI Denpasar, Covid-19}

The aims of preparation this article to describe the results of the Real Work Lecture (KKN)this activities carried out by students of the Indonesian Art Institute (ISI) Denpasar on the implementation of KKN for the 2020 period. As one of the activities Tri Dharma Perguruan Tinggi, the implementation of KKN ISI Denpasar is the implementation of the learning outcomes obtained by students in the college. The different of the implementation of KKN in the previous years, with regards to the Corona Virus Disease (Covid-19) pandemic, the activities of KKN are directed at increasingly the capacity of students by being directly involved in the actively participating it is making efforts to help the people in their respective areas for prevention, to breaking out the chain spread of Covid-19. During the KKN 2020, students were divided into several groups where in each group there were students from various study programs. In Group 16 there were 8 students from the Fashion Design Study Program, the Dance Study Program, the Performing Arts Education Study Program, the Puppetry 
Study Program, the Karawitan Study Program, and the Pure Arts Study Program. The programs work carried out by students are in accordance with the fields studied in each study program. In this regard, in the article there are several topics related to the work program being carried out, the realization of the work program and the inhibiting and supporting factors of the work program. The method used in the writing this article is a qualitative method where the datas are obtained from the results of the students activity reports then the datas are analyzed and described in accordance with scientific writing rules. The conclusion of this paper is an analysis of the results of students work programs, the realization of work programs as well the factors that have become obstacles and support for the implementation of KKN during the Covid-19 pandemic.

Key words: KKN, ISI Denpasar, Covid-19

Proses review: 1 - 4 Mei 2021, Dinyatakan lolos 5 Mei 2021

\section{PENDAHULUAN}

Kuliah Kerja Nyata (KKN) merupakan salah satu kegiatan Tri Dharma Perguruan Tinggi yang wajib dilaksanakan oleh setiap mahasiswa Institut Seni Indonesia (ISI) Denpasar. Melalui mata kuliah ini mahasiswa diharapkan mampu beradaptasi dengan masyarakat, menerapkan berbagai pengetahuan yang dimiliki untuk membantu meningkatkan kondisi masyarakat sesuai dengan bidang ilmu yang dipelajari. Kegiatan KKN ISI Denpasar memiliki spesifikasi yang berbeda dengan kegiatan KKn yang dilaksanakan oleh perguruan tinggi lainnya. Sebagai institusi seni, kegiatan KKN mahasiswa ISI Denpasar difokuskan untuk membantu meningkatkan ketahanan seni dan budaya melalui penggalian, pelestarian, pengembangan potensi seni budaya yang terdapat di masyarakat.

Pelaksanaan KKN-ISI Denpasar pada periode tahun 2020 berbeda dengan pelaksanaan KKN pada tahuntahun sebelumnya. Perbedaan ini disebabkan oleh karena merebaknya penyebaran Covid-19 di seluruh Bali. Sebagaimana fenomena yang terjadi di seluruh wilayah Indonesia, khususnya di Bali, pandemic Covid-19 berdampak secara signifikan terhadap perbagai aspek kehidupan masyarakat, termasuk salah satunya di bidang pendidikan. Di sektor pendidikan tinggi, berbagai kegiatan tri dharma sempat ditiadakan untuk memutus penyebaran virus tersebut. Hal ini tentunya menimbulkan permasalahan yang sangat besar karena pendidikan sebagai upaya untuk mencerdaskan kehidupan bangsa harus dihentikan. Berbagai kebijakan akhirnya dikeluarkan oleh pemerintah, khususnya Kementerian Pendidikan dan Kebudayaan untuk mengatasi permasalahan tersebut. Sebagaimana Surat Edaran yang diterbitkan oleh Direktur Jenderal Pendidikan Tinggi Republik Indonesia Nomor 1 Tahun 2020 Tentang Pencegahan Penyebaran Corona Virus Disease (Covid-19) Di Perguruan Tinggi, Kementerian Pendidikan Dan Kebudayaan, dijelaskan selama masa pandemi infeksi Covid-19, Pimpinan PTN dan LL Dikti melakukan penyesuaian terhadap waktu pelaksanaan kegiatan Tri Dharma Perguruan Tinggi, dengan melakukan dan mengatur tatakerja serta mekanisme proses belajar mengajar, penelitian dan pengabdian (seperti Belajar Jarak Jauh, remote office, dan lain lain). Pada bagian lain dalam surat edaran tersebut juga diuraikan pembelajaran jarak jauh sangat dianjurkan untuk PTN/PTS di daerah Jabodetabek, Bandung, DI Yogyakarta, Solo, Semarang, Malang, Surabaya, Bali, dan Manado serta daerah lain yang sudah terkonfirmasi terdapat suspect-Covid 19.

Masuknya daerah Bali sebagai salah satu wilayah pandemic Covid-19 menyebabkan civitas akademika ISI Denpasar melaksanakan tri dharma sesuai dengan edaran tersebut. Sistem pembelajaran dilaksanakan metode belajar jarak jauh dengan menggunakan berbagai aplikasi zoom meeting, Google Meet, Google Classroom. Demikian pula halnya dengan kegiatan penelitian dan pengabdian kepada masyarakat, semuanya dilaksanakan sesuai dengan surat edaran dari Dirjen Dikti dan dipadukan dengan kebijakan yang dikeluarkan oleh Pemerintah Propinsi Bali. Seiring dengan kondisi yang semakin 
membaik, untuk memaksimalkan kegiatan KKN sebagai implementasi program tri dharma perguruan tinggi, ISI Denpasar melalui Lembaga Penelitian Pengabdian Kepada Masyarakat dan Pengembangan Pendidikan (LPMPP) mengeluarkan kebijakan terkait dengan pelaksanaan KKN pada masa pandemic Covid-19. Seperti dilansir di dalam buku Panduan Petunjuk Teknis Pelaksanaan Kuliah Kerja Nyata (KKN) ISI Denpasar Pada Masa Covid-19 disebutkan KKN ISI Denpasar di masa Covid-19 dilaksanakan di desa asal/tempat tingal masing-masing ini diharapkan mampu menjadi sarana penggerak partisipasi aktif masyarakat dalam mencegah dan menanggulangi bencana Covid-19 dengan mengangkat program terkait seni budaya yang menjadi unggulan masyarakat setempat.

KKN ISI Denpasar tahun 2020 diikuti oleh 397 orang mahasiswa yang terbagi dalam 48 kelompok. Dari jumlah tersebut delapan orang mahasiswa tergabung di dalam kelompok 16 yang menjadi bimbingan penulis. Adapun para mahasiswa tersebut adalah: Ni Putu Leslyani dari Program Studi Seni Tari; Ni Putu Ayu Putri Artini dari Program Studi Desain Mode; Agus Eka Wahyuwiarsana dari Program Studi Produksi Film dan Televisi, I Gede Nanda Krisdiawan dari Program Studi Pendidikan Seni Pertunjukan, I Komang Arsana dari Program Studi Pedalangan, I Gede Ngurah Bayu Pratama dari Program Studi Seni Karawitan, I Wayan Gede Prianta dari Program Studi Seni Karawitan, dan I Wayan Edi Apriawan dari Program Studi Seni Murni. Ke delapan mahasiswa peserta KKN tersebut masing-masing membuat program kerja sesuai dengan bidang studi yang dimiliki yang selanjutnya dipadukan dengan situasi dan kondisi masyarakat yang ada di wilayah domisili masing-masing mahasiswa atau di desa lain yang masih berdekatan dengan tempat tinggalnya.

Selama kurang lebih sebulan pelaksanaan KKN, terdapat berbagai fenomena yang dihadapi oleh para mahasiswa di masing-masing lokasi. Untuk itu dalam tulisan ini akan diungkap beberapa hal yang berkaitan dengan program kerja, realisasi program kerja serta beberapa faktor penghambat dan pendukung di dalam pelaksanaan program kerja.

\section{METODE}

Artikel pelaksanaan KKN ISI Denpasar ini dideskripsikan dengan menggunakan metode kualitatif. Data diperoleh melalui laporan akhir masing-masing mahasiswa sesuai dengan kegiatan yang dilaksanakan di masing-masing lokasi. Terdapat delapan lokasi KKN mahasiswa pada kelompok 16 yaitu Desa Adat Anggungan, Kelurahan Lukluk, Kecamatan Mengwi Kabupaten Badung, Desa Penyaringan, Kecamatan Mendoyo Kabupaten Jembrana, Desa Batubulan, Kecamatan Sukawati Kabupaten Gianyar, Banjar Puspasari, Desa Pujungan Kecamatan Pupuan Kabupaten Tabanan, Desa Lembongan, Kecamatan Nusa Penida Kabupaten Klungkung, Desa Mengwi, Kecamatan Mengwi Kabupaten Badung, Desa Tumbak Bayuh, Kecamatan Mengwi Kabupaten Badung, Banjar Patolan, Desa Pering, Kecamatan Blahbatuh Kabupaten Gianyar. Dilakukannya KKN di masing-masing desa tersebut karena desa tersebut merupakan wilayah tempat tinggal para mahasiswa. Hal ini sesuai dengan arahan dari Panitia KKN ISI Denpasar dimana kegiatan KKN selama Pandemik Covid-19 dilakukan di daerah asal mahasiswa. Data dari masing-masing mahasiswa selanjutnya dilakukan analisis dari program kerja, pelaksanaan program hingga hasil akhir dari program kerja tersebut. Hasilnya analisis data tersebut disajikan secara deskriptif sesuai dengan kaidah penulisan artikel ilmiah.

\section{PROGRAM KERJA DAN HASIL YANG DICAPAI}

Kegiatan KKN ISI Denpasar 2020 yang dilaksanakan secara penuh selama satu bulan dari tanggal 1 hingga 32 Agustus 2020 telah menghasilkan berbagai kegiatan yang sangat bermanfaat bagi masyarakat. Selain program yang ditetapkan, mahasiswa peserta KKN juga ikut membantuk program pemerintah di dalam penanggulangan penyebaran virus corona sehingga pelaksanaan $\mathrm{KKN}$ ini mendapat apresiasi yang sangat positif dari masyarakat dan pemerintah desa. Sebagaimana yang dilaporkan oleh masingmasing mahasiswa bahwa program kerja yang rencanakan dapat berjalan dengan baik walaupun dalam situasi yang kurang menguntungkan akibat perkembangan virus corona. Ni Putu Lesliani yang melaksanakan KKN di Desa Anggungan, Kecamatan Mengwi-Badung melaporkan bahwa program pembinaan tari yang direncanakan bagi anak-anak yaitu tari Rejang Dewa, Condong, Sekar Jagat dan tari Rejang Dewa, serta Rejang Sari bagi kalangan remaja dapat dituntaskan dan dari evaluasi yang dilakukan keseluruhan materi tersebut dapat dikuasai dengan baik oleh anak-anak dan remaja di desa tersebut. 
Berbeda dengan yang dilakukan Ni Putu Lesliyani, di Desa Batubulan, Agus Eka Wahyu Wiarsana membuat program kerja yang sesuai dengan latar belakang keilmuannya. Adapun program yang dibuat oleh Wahyu adalah ahasiswa yang melaksanakan KKN Di Desa Batubulan yaitu video Informatif Company Profile Tentang Desa Batubulan Melawan Covid-19. Pembuatan video ini bertujuan untuk mempromosikan sekaligus memberitahu masyarakat Desa Batubulan kususnya tentang penanganan covid-19 yang sudah di lakukan pihak desa Batubulan. Selain membuat video tersebut, Wahyu berkolaborasi dengan mahasiswa KKN Universitas Udayana juga membuat video company profile tentang potensi Desa Batubulan yang bertujuan untuk mempromosikan potensi seni, budaya, pertanian serta objek wisata yang terdapat di wilayah Desa Batubulan.

Di lokasi yang lain I Gede Prianta dan I Gede Ngurah Bagus Pratama melakukan pembinaan seni karawitan untuk kalangan siswa dan remaja di lokasi KKN masing-masing sesuai dengan program kerja yang direncanakan. Di Desa Penyaringan, Kecamatan Mendoyo Kabupaten Jembrana, Ni Putu Ayu Putri Artini mahasiswa program studi Desain Mode melaksanakan program kerja pembuatan masker dan membagikannya kepada masyarakat di desa serta membantu pelaksanaan program desa di dalam penanggulangan pandemic covid-19. Program yang cukup menarik juga dilaksanakan oleh I Komang Arsana dari prodi Pedalangan yaitu memberikan himbauan kepada masyarakat ataupun pedagang melalui poster-poster yang ditempel di warung-warung, balai banjar dan diberbagai tepat strategis lainnya. Kegiatan ini secara langsung dibantu oleh kepala desa serta masyarakat setempat dan merupakan salah satu bentuk sosialisasi agar masyarakat bisa memahami bahaya Virus Covid-19 ini. Sesuai dengan bidang ilmunya, I Komang Arsana juga mengajarkan cerita rakyat/ masatua kepada anak-anak SD untuk menghilangkan rasa jenuh selama berdiam diri di rumah. Kegiatan tersebut dilakukan untuk menyadarkan masyarakat tentang bahayanya Virus Covid-19 ini, dan supaya masyarakat bisa menjaga kesehatan dirinya sendiri dan menjaga keluarga mereka dari wabah pandemi ini.

Pelatihan dasar bermain drama dan belajar karawitan diberikan oleh I Gede Nanda Krisdiawan seorang mahasiswa dari Prodi Pendidikan Seni Pertunjukan. Kegiatan ini diikuti oleh siswa SMP di Desa Lembongan Nusa Penida dan hasilnya dipentaskan pada hari terakhir pelaksanaan KKN di daerah tersebut. Program yang sangat menarik yaitu belajar menggambar dan melukis mural bertema wayang dilaksanakan oleh I Wayan Widi Apriana dari Prodi Seni Murni kepada kalangan generasi muda Di Desa Tumbak Bayuh, Kecamatan Mengwi Badung. Kegiatan ini sangat positif bagi kalangan generasi muda di wilayah tersebut karena melalui belajar menggambar dan melukis mural bertema wayang nantinya akan dapat meningkatkan wawasan mereka tentang seni lukis dan bermanfaat bagi kehidupan mereka pada masa yang akan datang. Dengan menggambar mural mereka dapat memanfaatkan dinding-dinding kosong untuk diisi lukisan wayang agar lebih menarik.

Mengamati kegiatan yang dilakukan oleh mahasiswa peserta KKN di masing-masing lokasi KKN, nampak peran generasi muda sangat tinggi dalam berbagai program kerja yang dilakukan. Keterlibatan generasi muda dalam berbagai kegiatan tersebut sangat baik di dalam upaya meningkatkan peran generasi muda dalam pelestarian dan pengembangan seni budaya.

\section{HAMBATAN DAN FAKTOR PEN- DUKUNG}

Pelaksanaan KKN ISI Denpasar pada masa pandemic covid-19 tentunya tidak luput dari berbagai hambatan yang dialami oleh mashasiswa di lokasi KKN. Hambatan tersebut beragam jenisnya, selain hambatan yang secara umum disebabkan oleh pandemic covid-19 juga terdapat hambatan yang disebabkan oleh karakteristik desa dan masyarakat di masing-masing lokasi. Sebagaimana dialami oleh Agus Eka Wahyu Wiarsana, selama menjalankan kegiatan KKN pada masa covid-19 di Desa Batubulan, Kecamatan Sukawati, Gianyar terdapat beberapa hal yang menghambat pengerjaan program kerja yang telah direncanakan sebelumnya. Faktor utama yang menghambat adalah sulitnya mengatur jadwal narasumber yang padat ataupun jadwal crew yang bertugas, karena pada dasarnya kami saling membantu dalam mengerjakan 17 program kerja masing-masing. Hal lain yang menjadi penghambat adalah kondisi cuaca yang tidak menentu sehingga menyulitkan dalam mengambil gambar dan video di lapangan. Di lokasi yang lain, I Wayan Arsana mengalami hambatan dalam melaksanakan program kerja karena masyarakat disibukkan dengan serangkaian upacara keagamaan dan perayaan 
17an yang diselenggarakan oleh masyarakat di Desa Pujungan. Di Desa Lembongan, Nusa Penida I Gede Nanda Krisdiawan mengalami hambatan dalam melaksanakan program karena para siswa tidak bisa fokus mengikuti arahan yang diberikan. Para siswa masih sering bermain-main dan tidak serius ketika diadakan pelatihan.

Pada kondisi yang lain, keberhasilan para mahasiswa menuntaskan program kerja adalah adanya dukungan yang positif dari komponen masyarakat terutama aparat desa dan masyarakat di masing-masing lokasi KKN. Seperti yang dialami oleh I Wayan Widi Apriana di Desa Tumbak Bayuh dikatakan bahwa Perbekel Desa Tumbakbayuh, seluruh kelian banjar dan masyarakat Desa Tumbakbayuh mendukung dengan positif saat kehadiran mahasiswa KKN untuk memberikan pengenalan, pemahaman dan pelatihan mengambar wayang dan mural. Sehingga para generasi di lingkungan Desa Tumbakbayuh sangat antusias dalam mengikuti setiap program kegiatan sehingga pelaksanaan program dan kegiatan lainnya dapat terlaksana dengan baik.

Adanya berbagai hambatan dan faktor pendukung tersebut merupakan persoalan yang selalu terjadi di dalam pelaksanaan program kerja KKN yang dilaksanakan oleh mahasiswa ISI Denpasar. Hal ini merupakan pembelajaran yang sangat berharga bagi setiap mahasiswa karena mereka nantinya akan selalu dihadapkan pada kondisi seperti ini. Akan ada hambatan baik teknis maupun non-teknis serta faktor pendukung di dalam melaksanakan program kerja dimasa yang akan datang. Bahwa seorang mahasiswa harus bisa beradaptasi dengan lingkungan yang baru dan berusaha memecahkan permasalahan yang terjadi di lapangan.

\section{SIMPULAN}

Berbagai pembahasan di atas berkenaan dengan pelaksanaan KKN ISI Denpasar pada masa pandemic covid-19 tahun 2020 dapat disimpulkan sebagai berikut.

Secara umum kedelapan orang mahasiswa peserta KKN ISI Denpasar yang tergabung dalam kelompok 16 telah melaksanakan kegiatan di delapan daerah lokasi KKN sesuai dengan wilayah tempat tinggalnya. Walaupun dalam masa pandemic covid-19, ke delapan orang mahasiswa tersebut telah sukses melaksanakan program kerja sesuai dengan rencana yang telah disusun sebelumnya. Bahkan beberapa orang mahasiswa berhasil menambah program baru di luar dari program kerja yang ditetapkan. Keikutsertaan mahasiswa dalam kegiatan KKN 2020, selain berhasil mengamalkan pendidikan yang dicapai di bangku kuliah kepada masyarakat, juga berhasil membangun potensi seni budaya dan sumber daya masyarakat di lokasi KKN. Keseluruhan program yang dilaksanakan lebih banyak melibatkan kalangan generasi muda dan mendapat dukungan dari aparat desa serta masyarakat setempat.

\section{DOKUMENTASI KEGIATAN KKN KELOMPOK 16.}

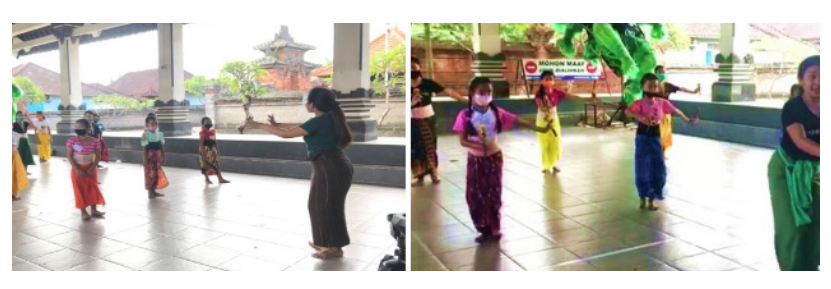

Palatihan gerak dasar tari Bali oleh Ni Putu Leslyani https://www.youtube.com/watch?v=jqJGDLmh-ZI

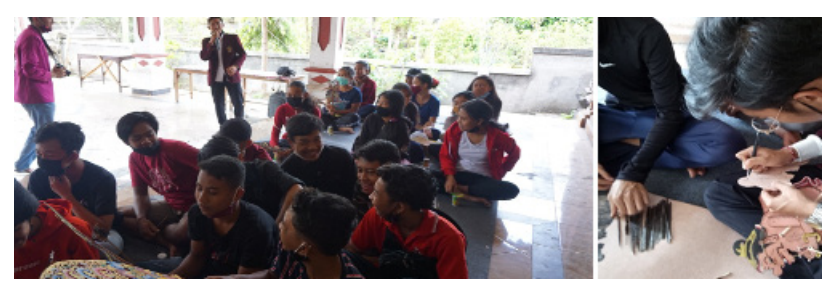

Pengenalan wayang oleh I Komang Arsana

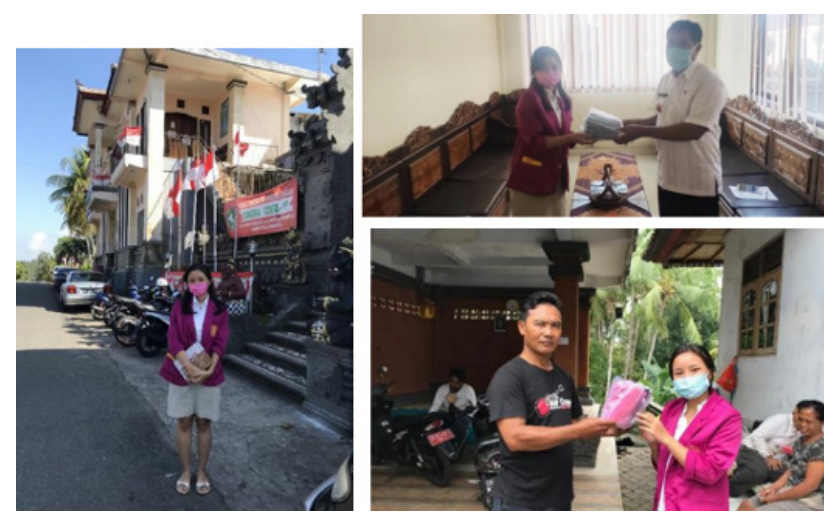

Pembagian Masker oleh Ni Putu Ayu Putri Artini https://youtu.be/LzJnROZB2B4 


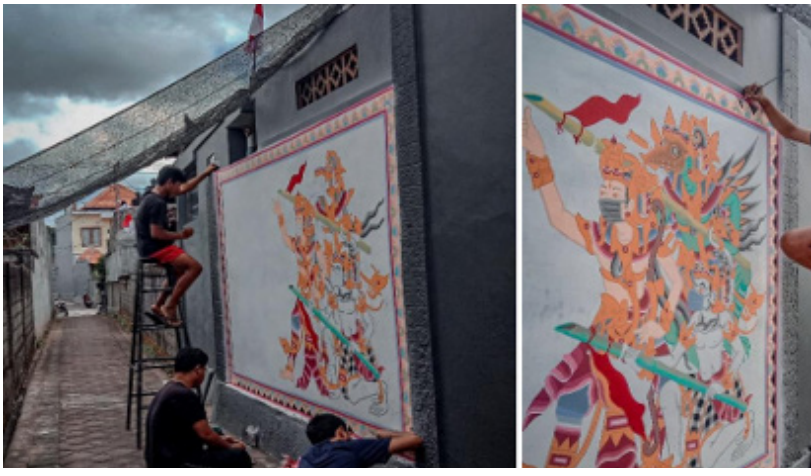

Hasil pelatihan menggambar mural wayang oleh I Wayan Widi Apriana

https://www.youtube.com/watch?v=_KRYWy-6SS8

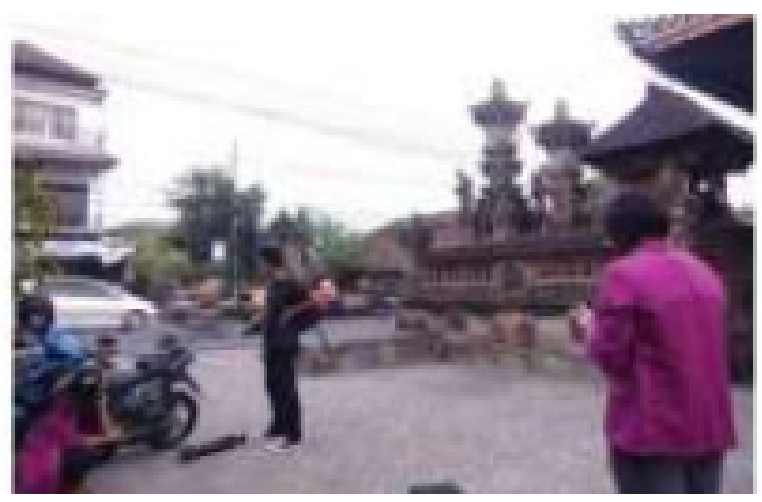

Pengambilan gambar oleh Agus Eka Wahyu Wiarsana https://www.youtube.com/watch?v=rlGg-wp9tLU\&t=7s

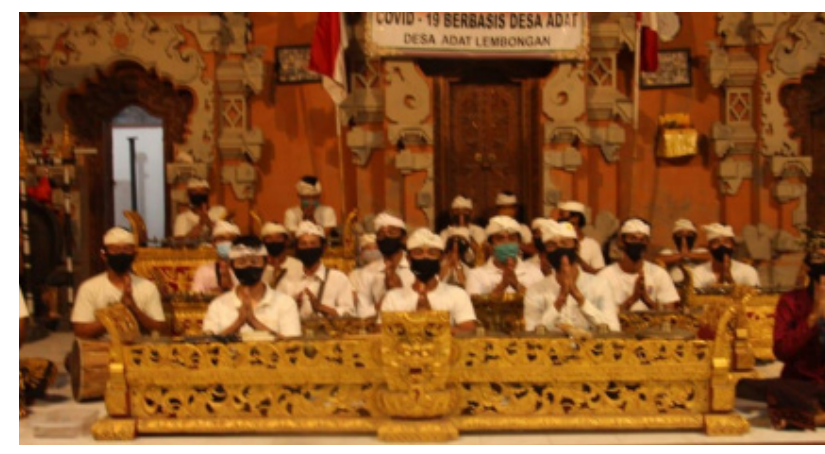

Penyajian hasil pembinaan seni karawitan I Gede Nanda Krisdiawan

https://youtu.be/vhfyNlVmKko

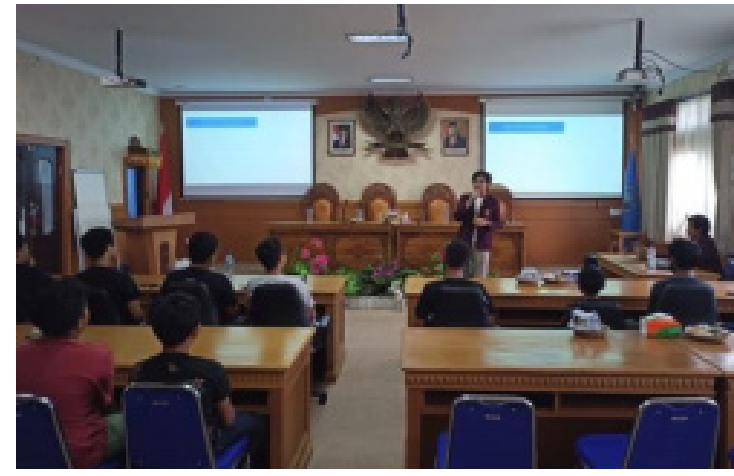

Pelatihan pembuatan musik melalui aplikasi frutiloop oleh I Gede Ngurah Bagus Pratama https://youtu.be/Eo5ce97jvGY

\section{DAFTAR PUSTAKA}

Apriana, I Wayan Widi. 2020. "Laporan Akhir Mahasiswa Kuliah Kerja Nyata Pada Masa Covid-19 Institut Seni Indonesia Denpasar Tahun 2020 Desa Tumbak Bayuh". Lembaga Penelitian Pengabdian Kepada Masyarakat Pengembangan Pendidikan (LP2MPP) Institut Seni Indonesia Denpasar.

Arsana, I Komang, 2020. "Laporan Akhir Mahasiswa Kuliah Kerja Nyata Pada Masacovid -19 Isntitut Seni Indonesia Denpasar Tahun 2020”. Lembaga Penelitian Pengabdian Kepada Masyarakat Pengembangan Pendidikan (LP2MPP) Institut Seni Indonesia Denpasar.

Artini, Ni Putu Ayu Putri. 2020. "Laporan Akhir Mahasiswa Kuliah Kerja Nyata Pada Masa Covid-19 Institut Seni Indonesia Denpasar Tahun 2020 Desa Penyaringan, Jembrana, Bali”. Lembaga Penelitian Pengabdian Kepada Masyarakat Pengembangan Pendidikan (LP2MPP) Institut Seni Indonesia Denpasar.

Krisdiawan, I Gede Nanda. 2020. "Mahasiswa Kuliah Kerja Nyata Pada Masa Covid-19 Institut Seni Indonesia Denpasar Tahun 2020 Di Desa Lembongan". Lembaga Penelitian Pengabdian Kepada Masyarakat Pengembangan Pendidikan (LP2MPP) Institut Seni Indonesia Denpasar.

Leslyani, Ni Putu. 2020. "Laporan Akhir Mahasiswa Kerja Nyata Pada Masa Covid-19 Institut Seni Indonesia Denpasar Tahun 2020 Desa Adat Anggungan, Kelurahan Lukluk, Kecamatan Mengwi, Kabupaten Badung”. Lembaga Penelitian Pengabdian 
Kepada Masyarakat Pengembangan Pendidikan (LP2MPP) Institut Seni Indonesia Denpasar.

Panduan Petunjuk Teknis Pelaksanaan Kuliah Kerja Nyata (KKN) ISI Denpasar Pada Masa Covid-19.

Pratama, I Gede Ngurah Bagus. 2020. "Laporan Akhir Mahasiswa Kuliah Kerja Nyata Pada Masa Covid -19 Institut Seni Indonesia Denpasar Tahun 2020". Lembaga Penelitian Pengabdian Kepada Masyarakat Pengembangan Pendidikan (LP2MPP) Institut Seni Indonesia Denpasar.

Prianta, I Wayan Gede. 2020. "Lapaoran Akhir Mahasiswa Kuliah Kerja Nyata Institut Seni Indonesia Denpasar Pada Masa Corona Virus Disease (Covid-19)". Lembaga Penelitian Pengabdian Kepada Masyarakat Pengembangan Pendidikan (LP2MPP) Institut Seni Indonesia Denpasar.

Wiarsana, Agus Eka Wahyu. 2020."Laporan Akhir Mahasiswa Kuliah Kerja Nyata Pada Masa Covid -19 Kelompok 16 Institut Seni Indonesia Denpasar Tahun 2020 Desa Batubulan”. Lembaga Penelitian Pengabdian Kepada Masyarakat Pengembangan Pendidikan (LP2MPP) Institut Seni Indonesia Denpasar. 